Editorial

\title{
An Uneasy Return to the Role of Popular Culture
}

\author{
Niall Brennan ${ }^{1, *}$, Frederik Dhaenens ${ }^{2}$ and Tonny Krijnen ${ }^{3}$ \\ ${ }^{1}$ Department of Communication, Fairfield University, USA; E-Mail: nbrennan@fairfield.edu \\ ${ }^{2}$ Centre for Cinema and Media Studies, Ghent University, Belgium; E-Mail: frederik.dhaenens@ugent.be \\ ${ }^{3}$ Department of Media and Communication, Erasmus University, The Netherlands; E-Mail: krijnen@eshcc.eur.nl \\ * Corresponding author
}

Submitted: 2 July 2021 | Published: 13 September 2021

\begin{abstract}
The editorial for the thematic issue of Media and Communication, “From Sony's Walkman to RuPaul's Drag Race: A Landscape of Contemporary Popular Culture," looks at the prevailing themes of earlier studies of popular culture, from Raymond Williams' organic culture to the postmodern embrace of commodity culture, in relation to the current cultural moment of disruption and unease. The editorial then synthesizes the articles contained in the issue against where the study of popular culture has been and where we may anticipate it going.
\end{abstract}

\section{Keywords}

commodification; political communication; popular culture; postmodernism

\section{Issue}

This editorial is part of the issue "From Sony's Walkman to RuPaul's Drag Race: A Landscape of Contemporary Popular Culture" edited by Tonny Krijnen (Erasmus University Rotterdam, The Netherlands), Frederik Dhaenens (Ghent University, Belgium) and Niall Brennan (Fairfield University, USA).

(C) 2021 by the authors; licensee Cogitatio (Lisbon, Portugal). This editorial is licensed under a Creative Commons Attribution 4.0 International License (CC BY).

The last year and a half, and going forward, have been and will continue to be uneasy periods for human existence. The Covid-19 pandemic has brought uncertainty, disruption, and trauma to all aspects of life we previously took for granted. Perhaps one area of pre-pandemic life that has gone unscathed, and arguably even flourished despite a global virus, is consumption of popular culture, even if the latter constitutes being alone while collectively consuming mass-produced culture (Coates, 2020), or producing one's own culture to share in the contingent, ever-changing public sphere (MacDonald, 2020). As heads of the Popular Culture working group of IAMCR, and as guest editors of this thematic issue of Media and Communication, we never imagined present circumstances when we conceived of revisiting the role of popular culture in contemporary life, and by no means is the issue dedicated to implications of the pandemic for contemporary popular culture. Nonetheless, we see this as an opportune moment to consider perspectives on where popular culture has been, and where it is going, in relation to the present-day climate which only seems to suggest continuity to unsettled social conditions.

Looking back, Raymond Williams (1974) crucially distinguished different kinds of popular culture. One kind is produced by the people to express their meanings and values, and another is produced for the people in which is engrained processes ranging from repressive imposition to commercial saturation by both internal and external forces. For Williams, as now, no clear-cut distinction exists between the former "organic" and latter "mechanistic" cultures (Shashidhar, 1997), although arguably it has become even more challenging to differentiate between lived reality and political ideology (Williams, 1983) as they intersect in popular culture, particularly in the contemporary moment, as many contributors to the issue address. What Williams may have resisted but now seems inevitable is that legitimization of the study of popular culture stems from Marxist traditions which recognize the role popular culture plays in mobilizing political action (Mukerji \& Schudson, 1986). But if the popular is 
political, as these moments of uncertainty and entries in this issue also evidence, so too is it commodified and consumption-driven, mostly although not entirely to the displeasure of cultural scholars (Adorno \& Horkheimer, 1979; Baudrillard, 1983; Hebdige, 1979; Jameson, 1984; Laclau \& Mouffe, 2001).

On the commodification of popular culture, and where Williams would likely shudder, Fiske (1989, p. 15) writes: "There is no 'authentic' folk culture to provide an alternative, and so popular culture is necessarily the art of making do with what is available." Not to suggest its decimation by way of commodification and consumption, however, Fiske (1989, p. 15) adds, "the study of popular culture requires the study not only of the cultural commodities out of which it is made, but also of the ways that people use them" and from which the latter promise "far more creative and varied" processes for exploration than do the former. Making use of, and endlessly reusing, the (exhausted) commodities of popular culture brings us somewhat naturally to the role postmodernism plays in intersecting lived reality and political ideology. Moreover, while intense interest in postmodernism as a framework for interpreting the (amenable) absorption of popular life into late-capitalism seems to have faded, it also seems inevitable to acknowledge that in the present moment commodification and consumption are precisely what continue to make the popular political, a premise the contributions to this issue additionally illustrate.

Apart from embracing commodification and consumerism, postmodernism implicates intertextuality and self-referentiality, simulacra and hyperreality, media convergence and interdependency, and the blank parody of pastiche in making sense of contemporary popular culture to suggest that the "easing out of the real in favour of its most appropriate representation makes it more difficult to talk about the media and society today" (McRobbie, 1986, p. 111). Equally so, it becomes increasingly difficult to assess the means of producing and consuming popular culture against ever-increasing profusion of popular forms themselves. However, despite critique of postmodernism, which would assert that the profusion of popular culture guarantees rights to consumption, not to access, that a "deadening" of reality signals realism devoid of investment, and that "recycling and ransacking of culture" results in an "inward-looking, second-hand aesthetic," postmodern inflections on popular culture also reveal distinct possibilities for articulating political agency (McRobbie, 1986, p. 114). For as much as postmodernism reflects the difficulties of fragmented existence, impermanence, and the futility of meaning when it was first reckoned with by cultural scholars, such conditions not only persist but provide grounds for political mobilization and action through popular culture in contemporary experience. Looking presently and forward, the authors contributing to this issue reflect many previous perspectives on popular culture in assessing where it is now and where it is going.
Hyzen and Van den Bulck (2021) analyse the nexus between conspiracy theories, "ideological entrepreneurs" and digital popular culture. They examine how digital popular culture serves to variously criticise, refute, and reinforce conspiracies as instrumental in pushing the latter and their propagators to the mainstream. The authors elaborate on the ideological entrepreneurs who play key roles in disseminating ideas that thrive in times of upheaval and alienation, and feed conspiracism. Digital popular culture works as ideological intermediaries in the relative power of various countercultures. Through discourse analysis of ideological entrepreneurs' digital communication strategies and remix/meme parodic culture, the authors find that (ironic) spectators can oppose or endorse ideological messaging through their own strategies. Cases of ideological entrepreneurship include Alex Jones, and the person(s) representing " $Q$ " of the conspiracymovement QAnon.

Pitcher's (2021) study takes up centuries-old fascination with the absurd and society's marvelling at those who deviate from physical and mental norms. Such fascinations peaked during nineteenth-century exhibits of those deemed too different for "normal" society. As science and human rights progressed, freak and travelling shows dwindled, yet fascination with freakishness remains. Research argues that freak discourse is intact, especially in some medical disciplines, and film studies literature is replete with analyses of the grotesque. Little work has plotted the role of freak discourse in creating reality television narratives. Pitcher argues that reality television mirrors the discourse used by freak shows to attract audiences and drive narratives, falling back on the same techniques used by sideshows and circuses, and hinging on faux-reality to construct similar narrative formulas. Three case studies from reality television further support how their narratives mirror traditional freak shows, and how human dignity is still belittled for the sake of entertainment.

Vázquez-Rodríguez et al. (2021) examine how queer teenagers use popular culture to seek information about themselves. Television plays a key role in LGBTQ+ youth identity-formation as means of providing information about sexuality, gender roles, and non-normative relationships unavailable in education and home. The authors analyse how protagonists of Netflix's Sex Education use popular media to explore their desires, fantasies, and gender expressions in forming queer identities in ways that illustrate the metatextual role audio-visual culture plays for audiences. Case studies include Adam, a bisexual teenager who masturbates to images of a 1980s actor, and Lily, whose roleplaying fantasies with alien creatures are influenced by Tank Girl, Alien, and fantasy fiction. The most revealing case of popular influence on queer youth identityformation is that of Eric, whose non-conforming gender expression follows the Hedwig and the Angry Inch transgender character to mark Eric's birthdays. 
Van Bauwel and Krijnen (2021) interrogate the gendered nature of popular media. Gendered audiences, genres, and production have been thoroughly examined, but perspectives on globalization and intersectionality leave room to examine popular media's relationship with gender. The authors investigate the meanings of intersectionality and globalization in the 2020 Super Bowl Halftime Show featuring Shakira and Jennifer Lopez. The performance resulted in hundreds of complaints of it being "too sexy," invoking the \#MeToo movement, sex trafficking, and corporate boycotts. Other spectators read the show differently to see representations of child abuse and slavery, suggesting how contradictory responses reveal complexity in relations between gender and popular media. The authors use discourse analysis of the video and articles reviewing the show to argue that intersectionality and globalization contribute to varying appraisals of gender performance. Moreover, the authors argue that age, motherhood, and geography are vital to interpreting the relations between gender and popular media.

While social-cultural change in young people's socialities can proceed slowly, the pervasiveness of social media in young people's lives pertains to changes in certain "qualities" by which sociality is understood. De Ridder (2021) interrogates change in qualities of social relationships, relating them to questions of values and beliefs central to data and surveillance capitalism, namely, how young people articulate values and beliefs of what constitutes "proper" intimacy, reputation, and popularity in social media imagery. Drawing on ethnographic research in which young people produced and reflected on Instagram accounts viewed as proper, inappropriate, or ideal, De Ridder examines the sematic universe in which sociality is understood by focusing on embodiment, data, and quantification logics, and the production and circulation of visuality. De Ridder argues that understanding data/surveillance capitalism is driven by goals of global companies whose data/surveillance strategies create value out of tracking people's activities, yet data/surveillance capitalism is also suffused with values and beliefs about "proper" intimacy, reputation, and popularity.

For Hermes and Teurlings (2021), popular culture is in a contradictory space. Popular culture is thriving in the expanding range of media objects studied under the rubric of "popular." Cultural studies scholars rarely examine these objects as popular culture, however. Instead, concerns about immaterial labour, voting behaviour, public opinion, societal polarisation, and populist authoritarianism are dominant frames of the contemporary media environment. The authors trace how such change has come to be, arguing that it reflects the technological media environment and cultural studies as an institutionalized project. The authors identify "the moment of popular culture" as cursory but groundbreaking, displaced by theoretical problems that gradually removed popular culture studies from the popu- lar. Displacements include: hollowing out of the popular as signalled by Morris (1988); misuse of "ethnography"; (perceived) moves towards and engagement with interpretative sociology; concern for neoliberalism and governmentality; and affect theory. The authors analyse how these moments mutated understanding of popular culture from hegemony and meaning-making to platforms for cultural citizenship and training grounds for docile subjects, and as commercial entertainment. Throughout the study, the authors link popular culture with political engagement as illustrative elements.

Dumitrica (2021) examines the identity-work performed in the use of transnational cultural resources in protest. The transnational symbolic dimension of the 2017 anti-corruption protests in Romania, evidenced in citizens' cultural references to Marvel superheroes, Charlie Hebdo, and Stalinist politics, was a striking feature of the movement. Dumitrica uses multimodal critical discourse analysis of protest posters to ask how transnational cultural resources are reinvested with local meanings to support the protest message, and how interplay between local and transnational meanings contribute to the construction of a collective protest identity. Dumitrica finds that protesters interchangeably addressed national and international audiences to simultaneously evoke and construct a cosmopolitan political imaginary. This cosmopolitan imaginary, however, remains permeated by hierarchies and decontextualised of (political) meaning.

\section{Conflict of Interests}

The authors declare no conflict of interests.

\section{References}

Adorno, T., \& Horkheimer, M. (1979). Dialectic of enlightenment. Verso.

Baudrillard, J. (1983). Simulations. Semiotext(e).

Coates, T. (2020, March16). As pandemic strikes, pop culture migrates to streaming sites. Wired. https:// www.wired.com/story/coronavirus-streaming-popculture

De Ridder, S. (2021). The banality of digital reputation: A visual ethnography of young people, reputation, and social media. Media and Communication, 9(3), 218-227.

Dumitrica, D. (2021). “Chuck Norris, please help!" Transnational cultural flows in the 2017 anticorruption protests in Romania. Media and Communication, 9(3), 239-248.

Fiske, J. (1989). Understanding popular culture. Unwin Hyman.

Hebdige, D. (1979). Subculture: The meaning of style. Methuen.

Hermes, J., \& Teurlings, J. (2021). The loss of the popular: Reconstructing fifty years of studying popular culture. Media and Communication, 9(3), 228-238. 
Hyzen, A., \& Van den Bulck, H. (2021). Conspiracies, ideological entrepreneurs, and digital popular culture. Media and Communication, 9(3), 179-188.

Jameson, F. (1984). Postmodernism, or the cultural logic of late capitalism. New Left Review, 146, 53-92.

Laclau, E., \& Mouffe, C. (2001). Hegemony and social strategy: Towards a radical democratic politics. Verso.

MacDonald, S. (2020). What do you (really) meme? Pandemic memes as social political repositories. Leisure Sciences, 43(1/2), 143-151.

McRobbie, A. (1986). Postmodernism and popular culture. Journal of Communication Inquiry, 10(2), 108-116.

Morris, M. (1988). Banality in cultural studies. Discourse, 10(2), 3-29.

Mukerji, C., \& Schudson, M. (1986). Popular culture. Annual Review of Sociology, 12(1), 47-66.
Pitcher, S. (2021). Here come my 600-pound quintuplets: A discussion of reality television as a freak discourse. Media and Communication, 9(3), 189-197.

Shashidhar, R. (1997). Culture and society: An introduction to Raymond Williams. Social Scientist, 25(5/6), 33-53.

Van Bauwel, S., \& Krijnen, T. (2021). Let's get loud: Intersectionally studying the Super Bowl's halftime show. Media and Communication, 9(3), 209-217.

Vázquez-Rodríguez, L.-G., García-Ramos, F.-J., \& Zurian, F. A. (2021). The role of popular culture for queer teen identities' formation in Netflix's Sex Education. Media and Communication, 9(3), 198-208.

Williams, R. (1974, November 22). On high and popular culture. The New Republic. https://newrepublic. com/article/79269/high-and-popular-culture

Williams, R. (1983). Culture and society, 1780-1950. Columbia University Press.

\section{About the Authors}
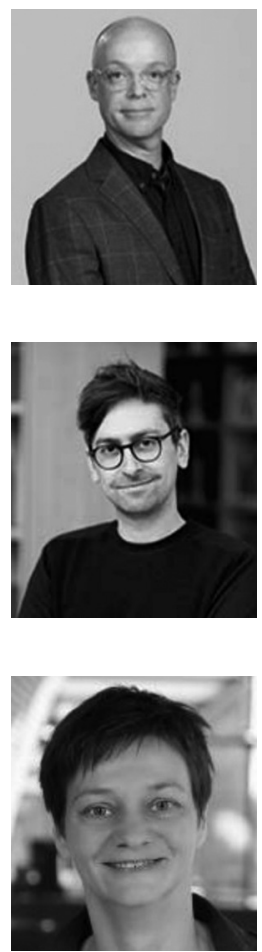

Niall Brennan is an Assistant Professor at Fairfield University whose research and teaching focus on gender and sexuality in the media, particularly on drag culture; on Latin American media history, forms and institutions; and on emerging communities of media consumers and producers. Niall is Vice-Chair of the Popular Culture Working Group, IAMCR.

Frederik Dhaenens is an Assistant Professor at Ghent University, where he teaches courses concerned with media, (popular) culture, and diversity. His research is situated in the field of critical media studies and cultural studies, while focusing on queer theory, LGBTQ representation, sex and sexuality, and masculinities in relation to popular culture, with a particular interest in television studies, popular music studies, and fan studies. Frederik is Vice-Chair of the Popular Culture Working Group, IAMCR.

Tonny Krijnen is Education Programme Director and Assistant Professor, Department of Media and Communication, Erasmus University Rotterdam. Her teaching and research lie in the fields of popular culture, morality, gender, television studies, and qualitative research methods. Her research focuses on television (content, production, reception), morality, gender, and emotions. She is involved in the Data Inspired Creativity project, is affiliated with the Erasmus Research Centre for Media, Communication, and is Chair of the Popular Culture Working Group, IAMCR. 